\title{
Phylogeny of the ring-forming bacterium Arcicella aquatica gen. nov., sp. nov. (ex Nikitin et al. 1994), from a freshwater neuston biofilm
}

Correspondence

Wolf-Rainer Abraham

wab@gbf.de

\author{
Denis I. Nikitin, ${ }^{1}$ Carsten Strömpl, ${ }^{2}$ M. S. Oranskaya ${ }^{1}$ \\ and Wolf-Rainer Abraham ${ }^{2}$ \\ ${ }^{1}$ Institute of Microbiology, Russian Academy of Sciences, Prospect 60-Letiya Octyabrya 7, \\ korp. 2, Moscow 117811, Russia \\ ${ }^{2}$ GBF - National Research Center for Biotechnology, Dept Environmental Microbiology, \\ Mascheroder Weg 1, 38124 Braunschweig, Germany
}

From a freshwater neuston film a slow-growing bacterial isolate, NO-502 ${ }^{\mathrm{T}}$, was obtained which formed rings consisting of several bacterial cells. Such a morphology is also known from some other bacterial genera, including Flectobacillus. In 1994, Nikitin and colleagues described this isolate as 'Arcocella aquatica' (Nikitin et al., 1994); however, no type species was deposited in a public culture collection and the description remained invalid. The aim of this note is to describe the genus and species validly and to give further information on the phylogenetic position of the type strain, $\mathrm{NO}-502^{\mathrm{T}}$.

Strain NO-502 $2^{\mathrm{T}}$ was isolated on a medium containing $0 \cdot 1 \%$ peptone, yeast extract and glucose each at $\mathrm{pH} 7 \cdot 0-$ $7 \cdot 2$ from a neuston film of a freshwater lake near Moscow, Russia. Cells are polymorphic, showing vibrioid, curved and spiral-shaped cells.

The sequence of the 16S rRNA gene of strain NO-502 ${ }^{\mathrm{T}}$ was determined as described previously (Abraham et al., 1999). It was found that an identical sequence was reported for isolate AH57 (accession no. AJ289964) from Lake Fuchskuhle, Germany (Glöckner et al., 2000). The latter isolate together with the sequence of uncultured bacterium GKS2-216 (accession no. AJ290033) from the same study

Published online ahead of print on 9 January 2004 as DOI 10.1099/ ijs.0.02896-0.

Abbreviations: $\mathrm{ESI}$, electrospray ionization; MS, mass spectrometry.

The GenBank/EMBL/DDBJ accession number for the 16S rRNA gene sequence of Arcicella aquatica NO-502 ${ }^{\top}$ is AJ535729. and the clone sequence GWF23A (accession no. AJ011696) from a cave water ecosystem could be considered to fall within the range of a common genus and to represent one or more additional species. These three undescribed organisms came, like strain $\mathrm{NO}-502^{\mathrm{T}}$, from freshwater ecosystems. Next relatives of this genus are species of the genus Flectobacillus, as shown in Fig. 1. The 16S rDNA sequence similarity between strain NO-502 ${ }^{\mathrm{T}}$ and the most similar published sequence of an organism with a validly published name, Flectobacillus major, is $93.52 \%$. Bootstrap analyses of neighbour-joining trees supported the phylogenetic association of Arcicella aquatica with Flectobacillus major (data not shown). The wide distribution of Flexibacter species throughout the phylum Bacteroidetes (Fig. 1) was discussed by Nakagawa et al. (2002). Nikitin et al. (1994), however, listed further genomic data which, together with our data, require the separation of strain $\mathrm{NO}-502^{\mathrm{T}}$ from the genus Flectobacillus. The $\mathrm{G}+\mathrm{C}$ content of strain NO$502^{\mathrm{T}}$ was found to be $34 \cdot 5 \%$, while a $\mathrm{G}+\mathrm{C}$ content of 39.5-40.3 mol\% has been reported for Flectobacillus major (Gosink et al., 1998).

Using tandem mass spectrometry (MS) the structures of many polar lipids of strain $\mathrm{NO}-502^{\mathrm{T}}$ could be elucidated using collision-induced decay MS by electrospray ionization (ESI) recorded in the negative mode [(-)-ESI] (Abraham et al., 1997). The phospholipids contained 2-N-(2'-Dhydroxyisopentadecanoyl)amino-3-hydroxyisoheptadeca4(E)-ene-1-phosphate. The phosphate was detected as $[M-1]^{-}$ion at $m / z 604$ in (-)-ESI MS. The corresponding aminoethyl derivative was detected at $\mathrm{m} / z 647$ and the 


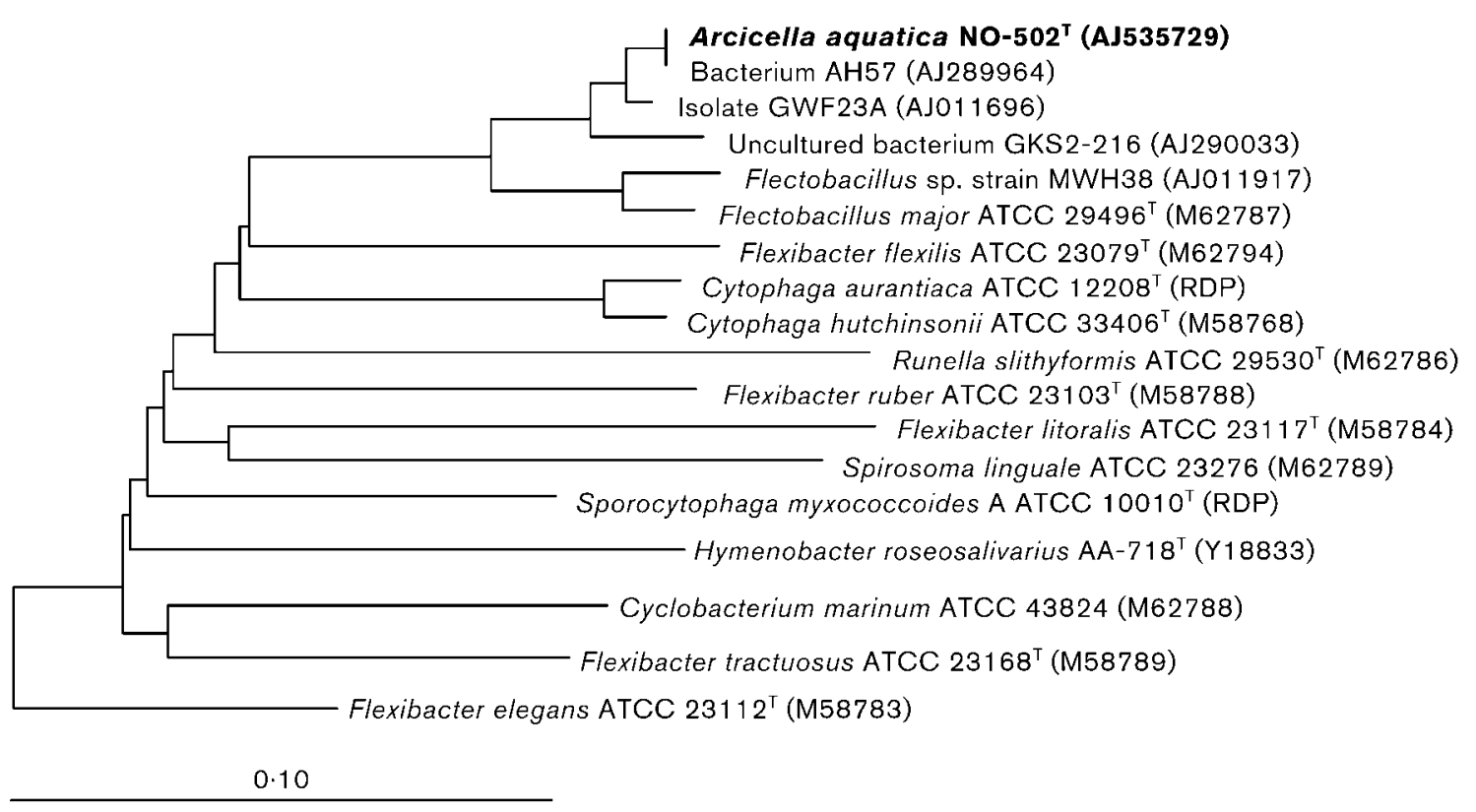

Fig. 1. Unrooted dendrogram based on the $16 \mathrm{~S}$ rDNA sequence of Arcicella aquatica NO-502 ${ }^{\top}$ within the context of the phylum Bacteroidetes. Sequence data of reference strains of other genera published in the GenBank/EMBL (Stoesser et al., 2003) and/or RDP (Cole et al., 2003) databases were obtained through the ARB database release June 2000 (http:// www.arb-home.de). Sequence data were aligned with the FASTALIGNER of the ARB program and adjusted manually. JukesCantor evolutionary distances were estimated using pair-wise sequence dissimilarities calculated with DNADIST, and the dendrogram was created with the FITCH program of the implemented PHYLIP package (Felsenstein, 1989). Bar, 10 nucleotide substitutions per 100 bases.

choline compound at $\mathrm{m} / \mathrm{z}$ 689. In addition, homologues to these phospholipids were detected. 2-D-(2'-D-Hydroxyisopentadecanoyl)amino-3-D-hydroxyisoheptadecane-1sulfonic acid was the only sulfolipid found in strain $\mathrm{NO}-502^{\mathrm{T}}$. The ion of a glycolipid was seen at $\mathrm{m} / z 729$ and identified as 2-N-(2"-hydroxyisopentadecanoyl)amino-3hydroxyisoheptadeca-4(E)-ene-1-hydroxycarbonyl-6-deoxy6-amino-mannopyranoside (Table 1). The latter compound has already been described from this strain and from
Flectobacillus major (Batrakov et al., 1999). Furthermore, three ions at $\mathrm{m} / z$ 977, 1181 and 1310 that belonged to unknown lipids were found in the lipid extract of strain $\mathrm{NO}-502^{\mathrm{T}}$.

In the lipid extract of Flectobacillus major, phosphatidylethylamine was found but not fully characterized; hence, a comparison with the three different compounds of this phospholipid from strain NO-502 ${ }^{\mathrm{T}}$ was not possible. While

Table 1. Polar lipids of Arcicella aquatica NO-502 ${ }^{\top}$ as determined by negative ESI quadrupole time-of-flight (ESI-OTOF) MS

\begin{tabular}{|c|c|}
\hline Mass $(\mathrm{Da})$ & Lipid \\
\hline 591 & 2-D-(2'-D-Hydroxyisopentadecanoyl)amino-3-D-hydroxyisoheptadecane-1-sulfonic acid \\
\hline 605 & 2- $N$-(2'-Hydroxyisopentadecanoyl)amino-3-hydroxyisoheptadeca-4(E)-ene-1-phosphate \\
\hline 648 & 2-N-(2'-Hydroxyisopentadecanoyl)amino-3-hydroxyisoheptadeca-4(E)-ene-1-(2"-aminoethyl)-phosphate \\
\hline 662 & 2-N-(2'-Hydroxyisopentadecanoyl)amino-3-hydroxyoctadeca-4(E)-ene-1-(2"-aminoethyl)-phosphate \\
\hline 675 & 1-Pentadecanoyl-2-hexadecenoylphosphatidyl-2'-ethylamine \\
\hline 687 & 1,2-bis-Hexadecenoylphosphatidyl-2'-ethylamine \\
\hline 689 & 1-Hexadecanoyl-2-hexadecenoylphosphatidyl-2'-ethylamine \\
\hline 730 & $\begin{array}{l}2^{\prime}-N-\left(2^{\prime \prime} \text {-Hydroxyisopentadecanoyl)amino-3' -hydroxyisoheptadeca-4' }(E) \text {-ene-1-hydroxycarbonyl-6-deoxy- }\right. \\
\text { 6-amino-mannopyranoside }\end{array}$ \\
\hline 978 & Unknown \\
\hline 1182 & Unknown \\
\hline 1311 & Unknown \\
\hline
\end{tabular}


2-D-(2'-D-hydroxyisopentadecanoyl)amino-3-D-hydroxyisoheptadecane-1-sulfonic acid and 2-N-(2'-hydroxyisopentadecanoyl)amino-3-hydroxyisoheptadeca-4(E)-ene-1(2"-aminoethyl)-phosphate were detected both in Flectobacillus major and in strain $\mathrm{NO}-502^{\mathrm{T}}$, their corresponding $2^{\prime}$-deoxy derivatives, the lipoamino acid $N$-[3-D-(isoheptadecanoyloxy)isoheptadecanoyl]-glycine and the lipopeptide $N-\left\{N^{\prime}-\left[3^{\prime \prime}\right.\right.$-D-(isoheptadecanoyloxy)isoheptadecanoyl]glycyl $\}$ L-serine were absent from strain $\mathrm{NO}-502^{\mathrm{T}}$ but present in Flectobacillus major (Batrakov et al., 2000). The homologue 2-N-(2'-hydroxyisopentadecanoyl)amino-3-hydroxyoctadeca-4(E)-ene-1-(2"-aminoethyl)-phosphate not known from Flectobacillus major is reported here for the first time.

The cellular fatty acids consisted mainly of even-numbered saturated fatty acids, while $\mathrm{C}_{16: 1} \omega 7 / t, \mathrm{C}_{18: 1} \omega 6$ and $\mathrm{C}_{18: 1} \omega 7$ were the main unsaturated fatty acids (Table 2). Strain $\mathrm{NO}-502^{\mathrm{T}}$ has higher proportions of $\mathrm{C}_{14: 0}$ and $\mathrm{C}_{16: 0}$ than Flectobacillus major, while $\mathrm{C}_{15: 1}$ and $\mathrm{C}_{17: 1}$, present in Flectobacillus major, are missing from strain $\mathrm{NO}-502^{\mathrm{T}}$ (Nikitin et al., 1994). The cellular fatty acid composition of strain NO- $502^{\mathrm{T}}$ is distinct from those of many type strains of the family Spirosomaceae, as $\mathrm{NO}-502^{\mathrm{T}}$ has low amounts of branched fatty acids (Urakami \& Komagata, 1986). However, these branched fatty acids are part of the sphingolipids of this strain, making it a clearly distinct member of this family.

Enzyme activities were determined using the API ZYM test and the results are given in Table 3. High activities of amino-acid-hydrolysing enzymes were found, even though strain $\mathrm{NO}-502^{\mathrm{T}}$ could not grow on amino acids; no lipase activity was observed. In the API ZYM test, catalase, $\beta$ galactosidase and $\beta$-glucosidase activities were observed, but no nitrate was reduced, no acids were produced by fermentation on glucose and no protease nor urease activity was found (Table 3). The nutritional requirements of strain $\mathrm{NO}-502^{\mathrm{T}}$ and Flectobacillus major were determined on a mineral medium $\left[0 \cdot 01 \mathrm{~g} \mathrm{KH}_{2} \mathrm{PO}_{4} \mathrm{l}^{-1}, 0 \cdot 1 \mathrm{~g} \mathrm{~K}_{2} \mathrm{HPO}_{4}\right.$ $\mathrm{l}^{-1}, 0 \cdot 2 \mathrm{~g}\left(\mathrm{NH}_{4}\right)_{2} \mathrm{HPO}_{4} \mathrm{l}^{-1}, 0 \cdot 03 \mathrm{~g} \mathrm{MgSO}_{4} \mathrm{l}^{-1}, 0 \cdot 01 \mathrm{~g} \mathrm{NaCl}$

Table 2. Polar lipid fatty acids (PL) and cellular fatty acids (TL) of strain NO-502

Values are given as a percentage of total fatty acids.

\begin{tabular}{|lcr|}
\hline Fatty acid & PL & TL \\
\hline $\mathrm{C}_{12: 0}$ & - & $7 \cdot 2$ \\
$\mathrm{C}_{14: 0}$ & - & $14 \cdot 7$ \\
$\mathrm{C}_{15: 0} \mathrm{i}$ & $6 \cdot 0$ & $5 \cdot 3$ \\
$\mathrm{C}_{16: 1} \omega 7$ & $44 \cdot 5$ & $11 \cdot 1$ \\
$\mathrm{C}_{16: 1} \omega 7 t$ & $19 \cdot 1$ & $7 \cdot 7$ \\
$\mathrm{C}_{16: 0}$ & $17 \cdot 3$ & $33 \cdot 6$ \\
$\mathrm{C}_{18: 1} \omega 6$ & $13 \cdot 1$ & $7 \cdot 2$ \\
$\mathrm{C}_{18: 1} \omega 7$ & - & $5 \cdot 1$ \\
$\mathrm{C}_{18: 0}$ & - & $8 \cdot 0$ \\
\hline
\end{tabular}

$\mathrm{l}^{-1}, 0 \cdot 01 \mathrm{~g} \mathrm{CaCl}_{2} \mathrm{l}^{-1}$, trace amounts of $\mathrm{MnSO}_{4}$ and $\mathrm{FeSO}_{4}$, $0.005 \%$ yeast extract; $\mathrm{pH} 7 \cdot 2$ ] with concentrations of $0.1 \%$ of the carbon sources (Nikitin et al., 1994). The substrates used differently by these two strains have been listed in Table 3 and compared with other type species of the family Spirosomaceae.

The 16S rRNA gene sequence similarity ( $93.5 \%$ and below) to related genera, and the differences in the polar lipids, the cellular fatty acids and biochemical and physiological characteristics between Flectobacillus major and strain NO$502^{\mathrm{T}}$ together with the differences in their $\mathrm{G}+\mathrm{C}$ contents do not allow the placement of these species in the same genus. Therefore, for strain NO- $502^{\mathrm{T}}$ Arcicella gen. nov. is proposed, with this strain as the type strain of Arcicella aquatica sp. nov.

\section{Description of the genus Arcicella gen. nov.}

Arcicella (Ar.ci.cel'la. L. masc. n. arcus the arc; L. fem. cella cell; N.L. fem. n. Arcicella arc-shaped cell).

Table 3. Biochemical characteristics of Arcicella aquatica $\mathrm{NO}-502^{\top}$ compared with related taxa

Taxa: 1, Arcicella aquatica $\mathrm{NO}-502^{\mathrm{T}} ; 2$, Flectobacillus major (Gosink et al., 1998); 3, Flexibacter flexilis; 4, Runella slithyformis; 5, Spirosoma linguale (Raj \& Maloy, 1990). Scale is from 0 (no reaction) to 5 (strong reaction); $\mathrm{W}$, weak reaction; -, no reaction; + , growth; ++ , abundant growth. NA, Not available. Strain NO$502^{\mathrm{T}}$ was unable to grow on monomethylamine, ethanol, alanine, glycine, valine, leucine, arginine, lasine, proline, cystine or tryptophan, whereas Flectobacillus major could (Nikitin et al., 1994); no data are available for these substrates for taxa 3-5.

\begin{tabular}{|c|c|c|c|c|c|}
\hline Assay & 1 & 2 & 3 & 4 & 5 \\
\hline Alkaline phosphatase & 5 & $+\ddagger$ & $\mathrm{NA}$ & $+\ddagger$ & $\mathrm{W} \ddagger$ \\
\hline Esterase (C4) & 3 & $-\ddagger$ & NA & $-\ddagger$ & - \\
\hline Acid phosphatase & 5 & $4+^{\star}$ & NA & $+\ddagger$ & $\mathrm{W} \ddagger$ \\
\hline$\beta$-Galactosidase & 5 & $+^{*}$ & NA & $+\ddagger$ & $+\ddagger$ \\
\hline Oxidase & NA & $+\ddagger$ & + & $+\ddagger$ & $+\ddagger$ \\
\hline Catalase & + & $\mathrm{W} \ddagger$ & - & $\mathrm{W} \ddagger$ & $+\ddagger$ \\
\hline Urease & - & $+\ddagger$ & NA & $-\ddagger$ & $-\ddagger$ \\
\hline Aesculin hydrolysis & + & $+^{*}$ & NA & $-\ddagger$ & NAł \\
\hline Acid production from glucose & - & $+\ddagger$ & + & $+\ddagger$ & $+\ddagger$ \\
\hline \multicolumn{6}{|l|}{ Growth on: } \\
\hline Succinate & - & $+\ddagger$ & NA & $-\ddagger$ & $+\ddagger$ \\
\hline Dulcitol & - & $+\dagger$ & NA & $-\ddagger$ & -† \\
\hline Acetate & + & $-\ddagger$ & NA & $-\ddagger$ & $-\ddagger$ \\
\hline Propionate & - & $++\dagger$ & $\mathrm{NA}$ & $-\ddagger$ & $-\ddagger$ \\
\hline Pyruvate & - & $++\dagger$ & NA & $-\ddagger$ & $+\ddagger$ \\
\hline Tyrosine & - & $++\dagger$ & NA & NA & NA \\
\hline Glutamate & - & $+\dagger$ & NA & $-\ddagger$ & $+\ddagger$ \\
\hline Aspartate & + & $+\dagger$ & NA & $\mathrm{NA}$ & NA \\
\hline
\end{tabular}

${ }^{\star}$ From Larkin \& Borrall (1984).

$\dagger$ From Nikitin et al. (1994).

‡From Raj \& Maloy (1990). 
The description is based on the one published by Nikitin et al. (1994). Cells are vibrioid, measure $2 \cdot 5-3 \cdot 0$ by $0 \cdot 5-$ $0.75 \mu \mathrm{m}$, and are stretched spirals or S-shaped. Colonies on solid media are mucous and light-orange pigmented. Growth occurs between 4 and $40^{\circ} \mathrm{C}$; the optimal growth temperature is $28-30^{\circ} \mathrm{C}$; optimal $\mathrm{pH}$ is around 7 . Grows with $\mathrm{NaCl}$ concentrations between 5 and $60 \mathrm{~g} \mathrm{l}^{-1}$; above these concentrations and without $\mathrm{NaCl}$ no growth is observed. Aerobic, do not grow on $\mathrm{C}_{1}$ compounds, amino acids or organic acids, but do grow on a wide range of carbohydrates. Biopolymers are not hydrolysed. Nitrate is not reduced. Main polar lipids are 2- $\mathrm{N}-\left(2^{\prime}\right.$-hydroxyisopentadecanoyl)amino-3-hydroxyisoheptadeca-4(E)-ene-1-(2"aminoethyl)-phosphate and its 3-hydroxyoctadeca-4(E)-ene homologues, phosphatidyl ethylamine, 2-D-(2'-D-hydroxyisopentadecanoyl)amino-3-D-hydroxyisoheptadecane-1sulfonic acid and 2- $\mathrm{N}$-(2"-hydroxyisopentadecanoyl)amino-3hydroxyisoheptadeca-4(E)-ene-1-hydroxycarbonyl-6-deoxy6-amino-mannopyranoside. Main fatty acids are $\mathrm{C}_{16: 0}$, $\mathrm{C}_{14: 0}, \mathrm{C}_{18: 1} \omega 6$ and $\mathrm{C}_{18: 0} . \mathrm{G}+\mathrm{C}$ content is $34 \mathrm{~mol} \%$. Lives in freshwater habitats.

Type species is Arcicella aquatica.

\section{Description of Arcicella aquatica sp. nov.}

Arcicella aquatica (a.qua.ti'ca. L. adj. aquatica aquatic; Arcicella species from water).

The description is the same as given for the genus with the following additions. Main phospholipids are 2-N-(2'hydroxyisopentadecanoyl)amino-3-hydroxyisoheptadeca$4(E)$-ene-1-(2"-aminoethyl)-phosphate, $2-N$ - $\left(2^{\prime}\right.$-hydroxyisopentadecanoyl)amino-3-hydroxyoctadeca-4(E)-ene-1(2"-aminoethyl)-phosphate, 1-pentadecanoyl-2-hexadecenoylphosphatidyl-2' -ethylamine, 1,2-bis-hexadecenoylphosphatidyl-2'-ethylamine and 1-hexadecanoyl-2-hexadecenoylphosphatidyl-2'-ethylamine. Cells display high activities of alkaline phosphatase, leucine and valine arylamidase, cystine arylamidase, trypsin, acid phosphatase, naphtholAS-BI-phosphohydrolase, $\beta$-galactosidase, $\alpha$-glucosidase, catalase and $N$-acetyl- $\beta$-glucosaminidase, weak activities of esterase lipase (C8), $\alpha$-chymotrypsin, $\alpha$-galactosidase, $\beta$-glucosidase and $\alpha$-fucosidase, and no activities of lipase $\left(\mathrm{C}_{14}\right), \alpha$-glucuronidase or $\alpha$-mannosidase. Nitrate is not reduced to nitrite or nitrogen. Grows well on glucose, fructose, lactose, maltose, rhamnose, galactose, arabinose, ribose, sucrose, cellobiose and inulin; shows some growth on mannitol, sorbitol, acetate and aspartate, but no growth on sorbose, dulcitol, ethanol, methanol, formate, propionate, pyruvate, monomethylamine, citrate, oxalate, succinate, malate or amino acids, with the exception of aspartate.

Type strain is $\mathrm{NO}-502^{\mathrm{T}}\left(=\mathrm{LMG} 21963^{\mathrm{T}}=\mathrm{CIP} 107990^{\mathrm{T}}\right)$. $\mathrm{G}+\mathrm{C}$ content is $34.5 \mathrm{~mol} \%$. Genome size is $2.9 \times 10^{9} \mathrm{Da}$. Isolated from a neuston film in the central part of Lake Trostenskoe near Zvenigorod in the Moscow region.

\section{Acknowledgements}

We thank Ina Buchholz and Jennifer Skerra for their skilful technical assistance. This work was supported by the grant 'Soil functions' of the HGF strategic funds.

\section{References}

Abraham, W.-R., Meyer, H., Lindholst, S., Vancanneyt, M. \& Smit, J. (1997). Phospho- and sulfolipids as biomarkers of Caulobacter sensu lato, Brevundimonas, and Hyphomonas. Syst Appl Microbiol 20, 522-539.

Abraham, W.-R., Strömpl, C., Meyer, H. \& 8 other authors (1999). Phylogeny and polyphasic taxonomy of Caulobacter species. Proposal of Maricaulis gen. nov. with Maricaulis maris (Poindexter) comb. nov. as the type species, and emended description of the genera Brevundimonas and Caulobacter. Int J Syst Bacteriol 49, 1053-1073.

Batrakov, S. G., Sheichenko, V. I. \& Nikitin, D. I. (1999). A novel glycosphingolipid from Gram-negative aquatic bacteria. Biochim Biophys Acta 1440, 163-175.

Batrakov, S. G., Mosezhnyi, A. E., Ruzhitsky, A. O., Sheichenko, V. I. \& Nikitin, D. I. (2000). The polar-lipid composition of the sphingolipid-producing bacterium Flectobacillus major. Biochim Biophys Acta 1484, 225-240.

Cole, J. R., Chai, B., Marsh, T. L. \& 8 other authors (2003). The Ribosomal Database Project (RDP-II): previewing a new autoaligner that allows regular updates and the new prokaryotic taxonomy. Nucleic Acids Res 31, 442-443.

Felsenstein, J. (1989). PHYLIP - Phylogeny inference package (version 3.2). Cladistics 5, 164-166.

Glöckner, F. O., Zaichikov, E., Belkova, N., Denissova, L., Pernthaler, J., Pernthaler, A. \& Amann, R. (2000). Comparative $16 S$ rRNA analysis of lake bacterioplankton reveals globally distributed phylogenetic clusters including an abundant group of actinobacteria. Appl Environ Microbiol 66, 5053-5065.

Gosink, J. J., Woese, C. R. \& Staley, J. T. (1998). Polaribacter gen. nov., with three new species, $P$. irgensii sp. nov., $P$. franzmannii sp. nov. and $P$. filamentus sp. nov., gas vacuolate polar marine bacteria of the Cytophaga-Flavobacterium-Bacteroides group and reclassification of 'Flectobacillus glomeratus' as Polaribacter glomeratus comb. nov. Int J Syst Bacteriol 48, 223-235.

Larkin, J. M. \& Borrall, R. (1984). Genus III. Flectobacillus Larkin, Williams and Taylor 1977, 152 ${ }^{\mathrm{AL}}$. In Bergey's Manual of Systematic Bacteriology, vol. 1, pp. 129-132. Edited by N. R. Krieg \& J. G. Holt. Baltimore: Williams \& Wilkins.

Nakagawa, Y., Sakane, T., Suzuki, M. \& Hatano, K. (2002). Phylogenetic structure of the genera Flexibacter, Flexithrix, and Microscilla deduced from $16 \mathrm{~S}$ rRNA sequence analysis. J Gen Appl Microbiol 48, 155-165.

Nikitin, D. I., Oranskaya, M. S., Pitryuk, I. A., Chernykh, N. A. \& Lysenko, A. M. (1994). A new ring-forming bacterium Arcocella aquatica gen. et sp. nov. Mikrobiologiya 63, 152-159 (in Russian).

Raj, H. D. \& Maloy, S. R. (1990). Proposal of Cyclobacterium marinus gen. nov., comb. nov., for a marine bacterium previously assigned to the genus Flectobacillus. Int J Syst Bacteriol 40, 337-347.

Stoesser, G., Baker, W., van den Broek, A. \& 13 other authors (2003). The EMBL Nucleotide Sequence Database: major new developments. Nucleic Acids Res 31, 17-22.

Urakami, T. \& Komagata, K. (1986). Methanol-utilizing Ancylobacter strains and comparison of their cellular fatty acid compositions and quinone systems with those of Spirosoma, Flectobacillus, and Runella species. Int J Syst Bacteriol 36, 415-421. 